\title{
The Impact of Institutional Investor Attention on Enterprise Performance: Empirical Test Based on Chain Multiple Mediating Effect Model
}

\author{
Ben Liu \\ School of Shenzhen Tourism, Jinan University, Shenzhen, China \\ Email address: \\ L1079194164b@163.com
}

To cite this article:

Ben Liu. The Impact of Institutional Investor Attention on Enterprise Performance: Empirical Test Based on Chain Multiple Mediating Effect Model. International Journal of Economics, Finance and Management Sciences. Vol. 9, No. 3, 2021, pp. 97-105.

doi: 10.11648/j.ijefm.20210903.11

Received: April 2, 2021; Accepted: May 8, 2021; Published: May 24, 2021

\begin{abstract}
In recent years, the number and types of institutional investors in China have achieved rapid development, and gradually become an important part of China's capital market. Institutional investors pay more attention to the long-term performance of enterprises in order to maintain their long-term and stable return on investment. This paper uses the investor relationship data of the "interactive easy" platform of Shenzhen Stock Exchange and the data of listed companies of Shenzhen Stock Exchange from 2014 to 2019 to construct the index of institutional investor attention, and empirically examines the influence mechanism of institutional investor attention on enterprise performance. Furthermore, a chain-type multiple intermediary effect model is constructed to investigate investor attention affecting enterprise performance. The results show that institutional investor attention can significantly improve enterprise performance. The attention of institutional investors can reduce the quality of economic development by increasing the innovation investment of enterprises and strengthening the incentive intensity of executive compensation, as well as the chain-type intermediary channel of "Executive Compensation Incentive Increase $\rightarrow$ Enterprise innovation investment increase", the independent intermediary effect of executive compensation incentive is the most prominent. Furthermore, the results show that institutional investor attention promotes the performance of non-state-owned enterprises and state-owned enterprises. However, the state-owned enterprises can only improve their performance through the compensation incentive independent intermediary channels.
\end{abstract}

Keywords: Institutional Investor Attention, Chain Intermediary Effect, Compensation Incentive, Innovation Investment, Enterprise Performance

\section{Introduction}

In recent years, Chinese institutional investors have achieved rapid development in number and type, and gradually become an important part of Chinese capital market. With the expansion of stock holding scale and the maturity of investment concept, in order to maintain their long-term and stable investment returns, institutional investors have turned more to long-term stock holding in the course of investment, increasing their attention to the long-term performance of enterprises, while institutional investors provide a large amount of financial support to enterprises, they also have a significant impact on the long-term performance of enterprises by participating in corporate governance.
Investor attention has become a hot topic. Existing literature has found that the research and attention of external investors to listed companies can reduce the inefficient investment level of enterprises [1], improve the return of stocks, reduce transaction costs and risks [2], promote the implementation of equity incentive plans [3], improve the innovation efficiency of enterprises [4], and influence the enterprise strategy [5]. The existing literature has enriched the research on the impact of Investor attention, but there are little literatures on the impact of enterprise performance. Does institutional investor concern have an impact on corporate performance? How does executive compensation incentive and enterprise innovation investment play a role in the relationship between institutional Investor attention and 
enterprise innovation investment?

Taking the listed companies of Shenzhen Stock Exchange of China from 2014 to 2019 as samples, this paper uses the "investor relations" data of Shenzhen Stock Exchange "interactive easy" platform to construct the "institutional investor attention" index to study the impact of institutional investor attention on the performance of listed companies. It is found that institutional investor attention plays an important role in promoting the performance of listed companies. The study further finds that institutional investor attention can not only improve enterprise performance through two independent intermediary channels: executive compensation incentive and increasing enterprise innovation investment, but also improve enterprise performance through the chain intermediary channel of "executive compensation incentive increases $\rightarrow$ enterprise innovation investment increases", that is, executive compensation incentive channel plays an independent intermediary effect and chain intermediary effect at the same time. Institutional investors participate in corporate governance through the general meeting of shareholders and other ways to promote the implementation of higher intensity of compensation incentive scheme and increase enterprise innovation investment and promote the improvement of enterprise performance. In order to obtain higher intensity of compensation incentive, executives will increase enterprise innovation investment, so as to promote the long-term performance of enterprises.

The contribution of this paper lies in the following aspects: firstly, the paper supplements the relevant literature of enterprise performance, puts forward the important role of institutional investor attention in promoting enterprise performance, and puts forward new ideas for promoting enterprise performance. Secondly, it complements the research on corporate governance mechanism of institutional investors. This paper finds that beyond institutional investor ownership, institutional investor attention also contributes to the increase of enterprise performance and innovation investment, thus promoting the long-term development of enterprises. It confirms the importance and effectiveness of institutional investors to the corporate governance mechanism. Thirdly, the method is innovative. This paper examines the impact of two mediations on enterprise performance: Executive Compensation Incentive and enterprise innovation investment through a chain intermediary model.

\section{Literature Review and Theoretical Assumptions}

At present, there are mainly two views on the impact of institutional investors on enterprise Performance: positive supervision hypothesis and ineffective supervision hypothesis. Scholars of positive supervision hypothesis believe that institutional investors have more ability and motivation to supervise enterprises than small and medium-sized investors, and will take relevant countermeasures. For example, institutional investors will use their advantages in scale, information and talents to help enterprises improve their performance [6]. As a part of the enterprise shareholders, institutional investors will actively supervise the management through shareholder litigation and other ways to improve the enterprise performance in order to maintain long-term investment income [7]. The higher the proportion of institutional ownership, the fewer defects in internal control, and the better enterprise performance [8]. The ineffective supervision hypothesis holds that institutional investors are speculative and will damage the value of the enterprise. Institutional ownership as a whole can not improve the degree and quality of voluntary information disclosure of listed companies [9]. Different types of institutional investors have different effects on enterprise performance. Stable institutional investors can improve enterprise financial performance more than transactional institutional investors [10].

Institutional investors are more willing and able to oversee enterprises than individual investors. The attention of institutional investors to listed companies can reduce the information asymmetry between institutional investors and listed companies. Institutional investors improve the decision-making efficiency of enterprises by participating in the general meeting of shareholders, and use the resources of institutional investors to help listed companies in a timely manner, and improve the performance of listed companies. Based on this, proposes the research hypothesis $\mathrm{H} 1$.

H1: There is a positive correlation between institutional investors attention and enterprise performance

Institutional investors have an impact on executive compensation design [11]. American mutual funds actively participate in corporate governance by requiring a higher percentage of enterprise executives to develop performance-related compensation incentive plans [12]. As institutional investors increase the performance-related portion of executive compensation, they also increase fixed compensation [12]. There is a significant positive correlation between institutional ownership and executive compensation and equity incentives in China [13]. Overall, institutional investors have a positive impact on executive compensation contracts, where the shareholdings of independent institutional investors are positively related to executive compensation-performance sensitivity [14]. According to the interest convergence assumption, the incentive to senior management will promote the connection between the interests of senior management and enterprise performance, thus promoting the improvement of enterprise performance. According to the theory of optimal compensation contract, the conclusion of compensation contract with senior managers can motivate them to work harder through the arrangement of compensation level [15]. Scholars have proved that both executive compensation incentive and equity incentive have positive impact on enterprise performance [16]. The compensation of top executives in central enterprises also contributed significantly to the improvement of enterprise performance [17].

In order to obtain a high return on investment, institutional 
investors will link the long-term performance of the enterprise with the remuneration of the senior management through the remuneration incentive plan. In order to obtain a high return on remuneration, the senior management of the enterprise will be consistent with the interests of shareholders and improve the performance of the enterprise. Based on this, we propose the assumption $\mathrm{H} 2$.

H2: Executive Compensation Incentive plays an intermediary role in the influence of institutional investor attention on enterprise performance.

Institutional shareholding can promote innovation investment of enterprises [18]. Enterprises with high investment in innovation perform better in terms of market value and market share, which is more conducive to the long-term development of enterprises [19]. In order to maintain their long-term and stable return on investment, institutional investors have shifted to long-term shareholding and paid more attention to the long-term value of enterprises in the process of investment [7]. Institutional investors can play the scale economic effect of information collection and the scope economic effect of supervision, so institutional investor attention can reduce the degree of information asymmetry, play the role of supervision and governance, and promote enterprise innovation [20]. Through the supervision mechanism, institutional investors can effectively reduce the short-sightedness problem of the management, use the fault tolerance mechanism to encourage the management of the enterprise to carry out innovation activities, and use the information and resource advantages of the institution through the knowledge spillover promotion mechanism to help the innovation activities of the enterprise [21].

On the research of innovation investment and enterprise performance, most scholars find that the increase of innovation input can promote the improvement of enterprise financial performance. The increase in $R \& D$ investment can improve productivity and financial performance of enterprises [22]. R\&D investment has a positive effect on enterprise performance, which is also affected by ownership and regional differences [23]. The $R \& D$ investment is lagging behind, and the increase of $R \& D$ investment has negative and positive correlation with the performance of enterprises in the current period and the next period [24].

In order to obtain the long-term stable return, the institutional investors will promote the enterprise to carry on the innovation investment. Enterprises with high investment in innovation will form new competitiveness and improve the performance of enterprises. Based on this, we propose the assumption $\mathrm{H} 3$.

H3: Enterprise R \& D investment plays an intermediary role in the process of institutional investor attention affecting enterprise performance.

\section{Research Design}

\subsection{Study Samples and Data Sources}

This paper selects the A-share listed company of Shenzhen
Stock Exchange from 2014 to 2019 as the research object. The A-share listed companies of Shenzhen Stock Exchange are selected because the investor concern degree adopted in this paper is taken as the measurement index. At present, only SZSE "interactive easy" has investor relations column. Because many enterprises have yet to disclose their annual reports, the figures are up to 2019. According to the research needs, the following items are excluded: (1) financial enterprises; (2) ST and *ST enterprises; the specially treated enterprises often have great difficulties in operating activities, and after hat removal or reorganization and other operating activities, leading to major changes in the main business, and the corresponding investment activities will have abnormal large fluctuation, which will affect the stability of the model. (3) Sample enterprise with missing data.

In the end, 8589 samples were obtained. With the exception of data from the Interactive Easy platform, all financial data comes from the Guotai Junan Securities Database (CSMAR).

\subsection{Variable Selection}

\subsubsection{Explained Variable}

Enterprise performance represents the enterprise final operating performance. This paper adopts the Return on total assets (ROA) as the standard to measure enterprise performance. The Return on total assets rate reflects the level of profit obtained by enterprises using assets and can fully reflect the efficiency of asset allocation and the results brought by business activities [25].

\subsubsection{Explanatory Variables}

Referring to the viewpoint of Cen (2017), this paper constructs the number of field research interviews or telephone interviews of institutional investors by using the data of investor relations activity record sheet on the "Interactive Easy" platform of Shenzhen Stock Exchange as the index of institutional investor attention. We used the variable INSTIFRE to represent The Times of field investigations and teleconferences of institutional investors of the enterprise in this year, and took the logarithm for processing [1].

\subsubsection{Intermediary Variable}

This paper borrows ideas and methods from Liu (2020) on the structure of executive compensation incentive. The logarithm of the highest three executive compensation amounts (INMPAY) is used to indicate the incentive level of executive compensation [26].

This paper refers to the viewpoint of Yu (2021) and adopts the logarithm of $R \& D$ (R\&D) investment. The $R \& D$ investment includes capitalization expenditure and expensed expense [27].

\subsubsection{Control Variables}

In order to analyze the R\&D investment and innovation performance of enterprises, this paper controls the following characteristic variables: free cash flow (FCF) of enterprises, dividing the free cash flow of the company by total assets; 
debt to asset ratio (LEV), using the ratio of total liabilities to total assets; proportion of independent directors (IND), using the proportion of independent directors in the enterprise; the proportion of the top 10 shareholders (H10), using the sum of the proportion of the top 10 shareholders; For the separation of the 2 positions (DUL), the chairman and the general manager shall be assumed by different personnel as 2, otherwise 1; the Tobin Q value (Tobin Q) shall be taken as the ratio of the enterprise market value to the book value; the enterprise scale (SIZE) shall be taken as the natural logarithm of the company total assets. In addition, Year and Ind virtual variables are used to control the impact of the year and industry.

\subsection{Model Settings}

\subsubsection{Overall Effect Test Model Setting}

The two-way fixed effect panel model is constructed to examine the overall effect of institutional investor attention on enterprise performance

$$
\mathrm{ROA}_{\text {it }}=\alpha_{0}+\alpha_{1} \text { INSTIFRE }_{\mathrm{it}}+\sum \text { control }_{\mathrm{it}}+\sum \text { Ind }+\sum \text { Year }+\varepsilon_{\mathrm{it}}
$$

Among them, $\mathrm{i}$ represents the enterprise, $\mathrm{t}$ represents the year, $\varepsilon$ represents the random interference item R\&D represents the enterprise R\&D investment, and INSTIFRE represents the attention of institutional investors

\subsubsection{Chain Multiple Mediating Effect Model}

In this paper, the chain multi-intermediation effect model is used to investigate the intermediation channels of institutional investor attention affecting enterprise performance [28]. According to the design idea of Liu (2009), the chain multiple mediation effect model is set as follows [29]:

$$
\begin{aligned}
& \text { INMPAY }_{\text {it }}=\beta_{0}+\beta_{1} \text { INSTIFRE }_{\text {it }}+\sum \text { control }_{\text {it }}+\sum \text { Ind }+\sum \text { Year }+\varepsilon_{i t} \\
& \mathrm{R}_{\mathrm{it}}=\gamma_{0}+\gamma_{1} \text { INSTIFRE }_{\mathrm{it}}+\gamma_{2} \text { INMPAY }_{\mathrm{it}}+\sum \text { control }_{\mathrm{it}}+\sum \text { Ind }+\sum \text { Year }+\varepsilon_{\mathrm{it}} \\
& \mathrm{ROA}_{\text {it }}=\eta_{0}+\eta_{1} \text { INSTIFRE }_{\text {it }}+\eta_{2} \text { INMPAY }_{\text {it }}+\eta_{3} \text { R\&D }_{\text {it }}+\sum \text { control }_{i t}+\sum \text { Ind }+\sum \text { Year }+\varepsilon_{\text {it }}
\end{aligned}
$$

Among them, ROA indicates enterprise performance, INSTIFRE indicates institutional investor attention, R\&D indicates enterprise innovation input, INMPAY indicates executive compensation incentive, and other settings are the same as equation (1). Equation (2) - (4) constitutes a multi-equation system. Equation (2) examines the impact of institutional investor attention on executive compensation incentive, equation (3) examines the effect of executive compensation incentive on enterprise innovation investment under the condition of controlling institutional investor attention, equation (4) examines the impact of enterprise innovation investment on enterpriaase performance under the conditions of controlling Institutional Investor attention and executive compensation incentives. In the model of chain multiple mediation effect, the mediation effect includes two kinds of independent mediation effect and chain mediation effect. Among them, the independent intermediary effect is represented as "institutional Investor attention increase $\rightarrow$ executive compensation incentive intensity increase $\rightarrow$ enterprise performance increase" and "institutional Investor attention increase $\rightarrow$ enterprise innovation investment increase $\rightarrow$ enterprise performance increase ", respectively recorded as independent intermediary effect 1 and independent intermediary effect 2 , their sizes are respectively $\beta_{1} \eta_{2}$ and $\gamma_{1} \eta_{3}$; chain intermediary effect is represented as" institutional Investor attention increase $\rightarrow$ executive compensation incentive intensity increase $\rightarrow$ enterprise innovation investment increase $\rightarrow$ enterprise performance increase ", their sizes are $\beta_{1} \gamma_{2} \eta_{3}$.

\subsubsection{Test Method of Intermediary Effect}

The traditional intermediate effect test mainly adopts the step-by-step method proposed by Baron (1986), which estimates each equation in the model separately, and then judges the existence of the intermediate effect according to the significance of the regression coefficient [30]. However, when the mediating effect involves multiple variables, the stepwise test of the regression coefficient will increase the probability of occurrence of the first type of statistical inference error [28]. In order to ensure the accuracy of the research results, referring to Dong (2020) method, this paper firstly uses the two-way fixed effect panel model to estimate the model (2)-(4) and makes a preliminary analysis on the mediation effect according to the estimated results; then, further, the equations (2)-(4) are developed to estimate the system, and the corresponding coefficient product of the mediation effect is examined by using the Bootstrap method [31].

\section{Empirical Results and Analysis}

\subsection{Descriptive Statistical Results and Correlation of Main Variables}

Table 1 shows descriptive statistical results for the main variables. From Table 2, the average institutional investor attention is 1.095 , which translates to an average of two surveys per listed company, the highest of which is 110 , it shows that there are great differences in the degree of attention of institutional investors among different enterprises. The average value of enterprise innovation investment is 17.879 , the minimum value is 0 , and the maximum value is 23.285, which indicates that different enterprise innovation investment is different. The average value of executive 
compensation incentive is 14.394 , and the difference between the maximum value and the minimum value is 5.776, indicating that the equity incentive degree of different enterprises is quite different. The average value of ROA is 0.042 , the maximum value is 0.675 and the minimum value is -1.859 , and the enterprise performance gap is large.

Table 1. Descriptive statistical results of main variables.

\begin{tabular}{|c|c|c|c|c|c|c|}
\hline Variable & Obs & Mean & Median & Std. Dev. & Min & Max \\
\hline $\mathrm{ROA}$ & 8589 & 0.042 & 0.042 & 0.078 & -1.859 & 0.675 \\
\hline R\&D & 8589 & 17.882 & 17.879 & 1.361 & 0 & 23.285 \\
\hline INMPAY & 8583 & 14.436 & 14.394 & 0.659 & 12.124 & 17.9 \\
\hline INSTIFRE & 8589 & 1.095 & 1.099 & 0.987 & 0 & 4.71 \\
\hline FCF & 8589 & 0.001 & 0.017 & 0.125 & -2.221 & 2.776 \\
\hline LEV & 8589 & 0.38 & 0.366 & 0.189 & 0.009 & 2.394 \\
\hline IND & 8589 & 0.378 & 0.364 & 0.055 & 0 & 0.75 \\
\hline DUL & 8589 & 1.664 & 2 & 0.472 & 1 & 2 \\
\hline Tobin Q & 8589 & 2.288 & 1.848 & 1.589 & 0.153 & 31.4 \\
\hline TAT & 8589 & 0.598 & 0.505 & 0.479 & 0.003 & 11.416 \\
\hline SIZE & 8589 & 21.966 & 21.846 & 1.091 & 19.138 & 28.179 \\
\hline
\end{tabular}

\subsection{Inspection of Chain Multiple Intermediary Effect of Institutional Investor Attention on Enterprise Performance}

Table 2 reports the estimation results of two-way fixed effects of equations (1) - (4). The model (1) takes the attention of institutional investors as the explained variable, and the coefficient of the attention of institutional investors is 0.01 , which is significant under $1 \%$, indicating that the attention of institutional investors has a significant effect on the increase of the Return on total assets, so the research hypothesis $\mathrm{H} 1$ is verified. Equation (2) takes executive compensation incentive as the explained variable, and the estimated coefficient of institutional investor attention is 0.091 , which is significant at the level of $1 \%$, indicating that the increase of institutional investor attention can promote executive compensation incentive. Equation (3) takes enterprise innovation investment as the explained variable, the estimated coefficients of executive compensation incentive and institutional investor attention are significant at the level of $1 \%$, and the coefficients of executive compensation incentive and institutional investor attention are 0.255 and 0.141 respectively. It shows that executive compensation incentive and institutional investor attention can promote the increase of innovation investment, and the influence of executive compensation incentive on enterprise innovation investment is higher than institutional investor attention. The result of equation (4) shows that on the basis of controlling other variables, the return on total assets is taken as the explained variable. The coefficients of enterprise innovation investment, executive compensation incentive and institutional investor attention are $0.003,0.008$ and 0.008 , which are significantly positive at the level of $1 \%$, indicating that enterprise innovation investor attention, executive compensation incentive and institutional investor attention can promote the improvement of enterprise performance. Columns (2) - (4) the empirical results show that institutional investor attention can improve enterprise performance through two intermediary channels: enhancing executive compensation incentive degree and increasing enterprise innovation investment. The following further uses bootstrap test to determine whether the intermediary channel exists significantly.

Table 2. Two-way results inspection

\begin{tabular}{|c|c|c|c|c|}
\hline \multirow{2}{*}{ Variable } & (1) & (2) & (3) & (4) \\
\hline & ROA & INPAY & R\&D & ROA \\
\hline R\&D & & & & $0.003 * * *(4.3)$ \\
\hline INMPAY & & & $0.255 * * *(14.12)$ & $0.008 * * *(5.7)$ \\
\hline INSTIFRE & $0.01 * * *(12.09)$ & $0.091 * * *(13.94)$ & $0.141 * * *(12.81)$ & $0.008 * * *(10.32)$ \\
\hline FCF & $-0.173 * * *(-35.17)$ & $0.135 * * *(2.93)$ & $0.015(0.2)$ & $0.18 * * *(31.81)$ \\
\hline LEV & $0.023 * * *(12.75)$ & $-0.361 * * *(-9.57)$ & $-0.363 * * *(-5.75)$ & $-0.167 * * *(-35.78)$ \\
\hline IND & $0.001 * * *(15.17)$ & $-0.096(-0.91)$ & $-0.167(-0.94)$ & $-0.006(-0.46)$ \\
\hline DUL & $-0.002(-1.42)$ & $-0.034 * * *(-2.72)$ & $-0.077 * * *(-3.67)$ & $-0.002(-1.16)$ \\
\hline Tobin Q & $-0.004(-0.3)$ & $0.048 * * *(11.06)$ & $0.021 * * *(2.82)$ & $0.004 * * *(7.16)$ \\
\hline TAT & $0.017 * * *(18.17)$ & $0.167 * * *(12.1)$ & $0.336^{* * *}(14.47)$ & $0.019 * * *(11.17)$ \\
\hline SIZE & $0.01 * * *(12.09)$ & $0.311 * * *(43.43)$ & $0.757 * * *(57.27)$ & $0.011 * * *(9.45)$ \\
\hline Year & YES & YES & YES & YES \\
\hline Ind & YES & YES & YES & YES \\
\hline Sample Size & 8589 & 8589 & 8589 & 8589 \\
\hline
\end{tabular}

Table 3 reports the results of the Bootstrap method test of the chain multiple mediation effect. It can be seen that the confidence interval corresponding to all mediating effect values does not include 0 , which indicates that independent 
mediating effect 1 , independent mediating effect 2 and chain mediating effect are significant, and the overall mediating effect is also significant. The results show that the attention of institutional investors can not only improve the performance of enterprises through two independent intermediary channels: increasing executive compensation incentive and increasing enterprise innovation investment, but also improve the performance of enterprises through the chain intermediary channel of "executive compensation incentive increase $\rightarrow$ enterprise innovation investment increase "that is, executive compensation incentive channel plays both independent intermediary effect and chain intermediary effect, assuming $\mathrm{H} 1$ and $\mathrm{H} 2$ are verified. In addition, from the size of the intermediary effect, the independent intermediary effect of the increase of innovation investment is the most prominent, followed by the independent intermediary effect of executive compensation incentive, and finally the chain intermediary effect of executive compensation incentive.

Table 3. Bootstrap Intermediate Effect Test Results.

\begin{tabular}{llll}
\hline Type of mediation effect & Mediated effect value & $\mathbf{9 5 \%}$ Confidence interval & Number of sampling \\
\hline Overall intermediary effect & 0.0148 & {$[0.0097,0.0204]$} & 5000 \\
Independent intermediary effect 1 & 0.0084 & {$[0.0046,0.0124]$} & 5000 \\
Independent intermediary effect 2 & 0.0056 & {$[0.002,0.0097]$} & 5000 \\
Chain intermediary effect & 0.0008 & {$[0.0003,0.0014]$} & 5000 \\
\hline
\end{tabular}

\subsection{Heterogeneity Test}

In order to further study whether the impact of institutional investor attention on enterprise performance is heterogeneous, this paper divides the sample into two sub-samples, state owned enterprises and non-state-owned enterprises, and examines them separately. Table 4 reports the results of institutional investor attention examines for different types of enterprise innovation. The results show that the estimated coefficients of institutional investor attention are all significantly positive at $1 \%$ level, indicating that institutional investor attention promotes the performance of non-state-owned enterprises and state-owned enterprises. However, the significant level of non-state-owned enterprises is stronger than that of state-owned enterprises, indicating that institutional investors are more effective in promoting the increase of innovation investment of non-state-owned enterprises.

Table 4. Estimated Overall Effect of Institutional Investor Attention on Enterprise Performance by Enterprise Nature.

\begin{tabular}{lll}
\hline \multirow{2}{*}{ Variable } & $\begin{array}{l}\text { State-owned } \\
\text { enterprises }\end{array}$ & $\begin{array}{l}\text { Non-state-owned } \\
\text { enterprises }\end{array}$ \\
\cline { 2 - 3 } & ROA & ROA \\
\hline INSTIFRE & $0.006^{* * *}(4.17)$ & $0.01^{* * *}(10.93)$ \\
Control variable & YES & YES \\
Year & YES & YES \\
Ind & YES & YES \\
Sample Size & 1715 & 6874 \\
$\mathrm{R}^{2}$ & 0.3883 & 0.3259 \\
\hline
\end{tabular}

Table 5 reports estimates of the two-way fixed effects for samples of state owned and non-state-owned enterprises. It can be seen that the coefficient symbols and significance of the main variables of non-state-owned enterprises are basically consistent with the results in table 3 . But in the state-owned enterprises, executive compensation incentives do not significantly contribute to innovation. It shows that executive compensation incentive does not promote innovation investment in state-owned enterprise.

Table 6 further reports the results of the Bootstrap method for the sample of state-owned and non-state-owned enterprises. The confidence intervals for the sample of non-state-owned enterprises do not include 0 , the results showed that independent mediator effect 1, independent mediator effect 2 and chain mediator effect existed significantly. Independent mediating effect and chain mediating effect of state-owned enterprises are not significant That is, for non-state owned enterprises, institutional investor attention can not only improve enterprise performance through two independent intermediary channels: increasing executive compensation incentives and increasing enterprise innovation investment, but also improve the performance of enterprises through the chain intermediary channel of "executive compensation incentive increase $\rightarrow$ enterprise innovation investment". But state-owned enterprises can only improve the performance of enterprises through independent intermediary channels of compensation incentive.

Table 5. Estimation Results of Chain Multiple Intermediary Effect Models for state-owned and non-state-owned enterprises.

\begin{tabular}{|c|c|c|c|c|c|c|}
\hline \multirow{2}{*}{ Variable } & \multicolumn{3}{|c|}{ State-owned enterprises } & \multicolumn{3}{|c|}{ Non-state-owned enterprises } \\
\hline & INPAY & R\&D & ROA & INPAY & R\&D & ROA \\
\hline R\&D & & & $0.003 * *(2.5)$ & & & $0.004 * * *(3.64)$ \\
\hline INMPAY & & $0.195(3.58)$ & $0.013 * * *(5.48)$ & & $0.264 * * *(14.41)$ & $0.006 * * *(4.06)$ \\
\hline INSTIFRE & $0.097 * * *(6.97)$ & $0.151 * * *(4.85)$ & $0.004 * * *(2.87)$ & $0.084 * * *(11.45)$ & $0.129 * * *(11.47)$ & $0.009 * * *(9.6)$ \\
\hline Control variable & YES & YES & YES & YES & YES & YES \\
\hline Year & YES & YES & YES & YES & YES & YES \\
\hline Ind & YES & YES & YES & YES & YES & YES \\
\hline Sample Size & 1715 & 1715 & 1715 & 6874 & 6874 & 6874 \\
\hline $\mathrm{R}^{2}$ & 0.5238 & 0.6448 & 0.4019 & 0.3425 & 0.5795 & 0.3294 \\
\hline
\end{tabular}


Table 6. Results of Bootstrap for mediating effects in state-owned and non state-owned enterprises.

\begin{tabular}{|c|c|c|c|c|c|c|}
\hline \multirow[b]{2}{*}{ Type of mediation effect } & \multicolumn{3}{|c|}{ State-owned enterprises } & \multicolumn{3}{|c|}{ Non-state-owned enterprises } \\
\hline & $\begin{array}{l}\text { Mediated } \\
\text { effect value }\end{array}$ & $\begin{array}{l}95 \% \text { Confidence } \\
\text { interval }\end{array}$ & $\begin{array}{l}\text { Number of } \\
\text { sampling }\end{array}$ & $\begin{array}{l}\text { Mediated } \\
\text { effect value }\end{array}$ & $\begin{array}{l}95 \% \text { Confidence } \\
\text { interval }\end{array}$ & $\begin{array}{l}\text { Number of } \\
\text { sampling }\end{array}$ \\
\hline Overall intermediary effect & 0.0353 & {$[0.0208,0.0512]$} & 5000 & 0.0115 & {$[0.006,0.0171]$} & 5000 \\
\hline Independent Mediating Effect 1 & 0.0294 & {$[0.0182,0.0426]$} & 5000 & 0.0052 & {$[0.0015,0.0091]$} & 5000 \\
\hline Independent Mediating Effect 2 & 0.0052 & {$[-0.0034,0.0144]$} & 5000 & 0.0055 & {$[0.0015,0.01]$} & 5000 \\
\hline Chain intermediary effect & 0.0007 & {$[-0.0005,0.0019]$} & 5000 & 0.0008 & {$[0.0002,0.0015]$} & 5000 \\
\hline
\end{tabular}

\section{Robustness Test}

In order to ensure the reliability of the empirical results, we replace the mediating variables and retest the mediating effect. Executive compensation incentives are measured in logarithms for the top three directors. The investment of enterprise innovation is measured by the proportion of $\mathrm{R} \& \mathrm{D}$ investment in total assets. Table 7 reports the estimated results of the two-way fixed effects of the equation (2) as (4) for the replacement medium variable. It can be seen that the coefficient symbols of the main variable are consistent with table 3 and are all significant at $1 \%$ or $10 \%$ level. In Table 8 , we report the results of Bootstrap mediating effect test after replacing the mediating variables. There are two kinds of independent mediating effects and chain mediating effects, and the independent mediating effect of executive compensation incentive is still the most prominent.

Table 7. Estimation Results of Chain Multiple Mediated Effect Model after Substituting Mediated Variables.

\begin{tabular}{llll}
\hline Variable & $\mathbf{( 1 )}$ & $\mathbf{( 2 )}$ & $\mathbf{( 3 )}$ \\
\cline { 2 - 4 } & Executive compensation incentive & Enterprise innovation inventment & Enterprise Performance \\
\hline R\&D2 & & & $0.097 * * *(2.86)$ \\
INMPAY2 & $0.108^{* * *}(14.86)$ & $0.004 * *(10.32)$ & $0.009 * * *(7.33)$ \\
INSTIFRE & YES & $0.002 * * *(8.86)$ & $0.008 * * *(10.34)$ \\
Control variable & YES & YES & YES \\
Year & YES & YES & YES \\
Ind & 1715 & YES & YES \\
Sample Size & 0.3097 & 1715 & 1715 \\
$\mathrm{R}^{2}$ & & 0.2672 & 0.4019 \\
\hline
\end{tabular}

Table 8. Test results of mediation effect by Bootstrap method after replacing mediated variables.

\begin{tabular}{llll}
\hline Type of mediation effect & Mediated effect value & $\mathbf{9 5 \%}$ Confidence interval & Number of sampling \\
\hline Overall intermediary effect & 0.0187 & {$[0.0129,0.0244]$} & 5000 \\
Independent Mediating Effect 1 & 0.0127 & {$[0.0084,0.0172]$} & 5000 \\
Independent Mediating Effect 2 & 0.0054 & {$[0.0016,0.0092]$} & 5000 \\
Chain intermediary effect & 0.0006 & {$[0.0002,0.0011]$} & 5000 \\
\hline
\end{tabular}

\section{Conclusion}

The institutional Investor attention is an important factor that affects the performance of enterprises. On the one hand, institutional investors will pay attention to enterprises by means of research, supervise and improve enterprises by means of general meeting of shareholders, promote the improvement of enterprise performance and promote institutional investors to obtain long-term and stable returns. On the other hand, institutional investors will promote the implementation of higher-intensity executive compensation incentive plans and increase the investment in innovation to promote the performance of enterprises.

This paper uses the "interactive easy" platform of Shenzhen Stock Exchange to construct the index of institutional Investor attention degree. Taking the data of listed companies of Shenzhen Stock Exchange of China from 2014 to 2019 as a sample, it examines the impact of institutional Investor attention degree on enterprise performance. The results show that the attention of institutional investors can significantly improve the performance of enterprises. The attention of institutional investors can not only improve the performance of enterprises through two independent intermediary channels, increasing executive compensation incentive and increasing innovation investment, but also improve the performance of enterprises through the chain intermediary channel of "increasing executive compensation incentive $\rightarrow$ increasing innovation investment". Among them, the independent intermediary effect of executive compensation incentive channel is the most prominent. Furthermore, the results show that institutional investor attention promotes the performance of non-state-owned enterprises and state-owned enterprises. However, the state-owned enterprises can only improve their performance through the compensation incentive independent intermediary channels.

The research conclusions of this paper are as follows: first, enterprises should pay attention to the impact of institutional investor attention, accept the research from external investors in a more open attitude, accept the suggestions from institutional investors, strengthen the relationship with investors, and promote the improvement of enterprise performance. Second, the regulatory authorities should attach 
importance to the positive role of information communication activities such as professional institutional investor research activities in improving the enterprise performance, and strive to open up more channels and platforms for external investors, especially professional and mature institutional investors to explore and communicate information. We will guide listed companies to participate more actively in the interaction and exchange with external investors, and accept the supervision and research of external investors in a positive and open manner. Third, enterprises should pay attention to the impact of innovation investment and senior management compensation incentives on enterprise performance. Increase the innovation investment of the enterprise, form the competitive advantage of the enterprise, promote the improvement of the long-term value of the enterprise, obtain stable and long-term returns, improve the incentive part of the remuneration of the senior management, link the performance of the enterprise with the remuneration of the senior management, implement the long-term incentive of the remuneration of the senior management, and promote the senior management to pay attention to the long-term performance of the enterprise. The interests of shareholders and senior management will converge to promote the role of senior management in improving enterprise performance and enterprise innovation investment.

\section{Research View}

In this paper, the number of research on investment institutions in "investor relations" on the interactive platform of Shenzhen stock exchange is used as the standard to measure the attention of institutional investors. In the past, most of the methods used to measure investor attention only indirectly represented investor attention, but did not find the direct behavior of investor attention. For example, the trading volume and turnover rate of stock are the trading characteristics and behaviors of financial market, which can not directly reflect the attention distribution of investors. The number of news reports, advertising costs and so on can only be converted into attention when investors read. The search volume of Internet search engines may still not be the most direct measure of investor attention. For example, a large number of searchers who participate in the search of listed companies may not be investors. The "investor relations" column on the interactive platform of Shenzhen stock exchange records the times, forms and questions and answers data of institutional investor representatives visiting the company, which more richly and directly represents investor attention to the company. Therefore, the following research can be carried out from the "investor relations" on the interactive platform of Shenzhen Stock Exchange. This platform includes the number of research institutions, the number of research institutions and research questions. These data can be used to study the attention of institutional investors. Follow up research can be carried out from this aspect.

\section{References}

[1] Cen Wei, Tong Naqiong \& Guo Qilin. (2017). Institutional Investor Concern and Corporate Inefficiency Investment - An Empirical Study Based on the Data of Shenzhen Stock Exchange Interactive Exchange Platform. Securities Market Journal, 10, 36-44.

[2] Cen Wei, Li Shihao \& Tong Naqiong. (2014). Impact of Investor Concern on Stock Returns and Risks: An Empirical Study Based on the Data of Shenzhen Interactive Exchange Platform. Securities Market Journal, 7, 40-47.

[3] Liu Jianqiu \& Cai Wenting. (2020). Impact of Investor Field Research on Enterprise Strategy Adjustment. International Business (Journal of University of Foreign Economics and Trade), 5, 141-156.

[4] Zhang Pei, Peng Feiran \& Hao Dongyang. (2020). Are institutional investors focused on promoting innovation of listed companies?- Empirical evidence based on the interactive platform of Shenzhen Stock Exchange. Journal of Capital University of Economics and Trade, 4, 103-112.

[5] Zhong Fang \& Wang Man. (2020). Can field investigation of institutional investors promote the implementation of equity incentive plans? Modern Finance and Economics (Journal of Tianjin University of Finance and Economics), $6,99-113$.

[6] Zhang Dixin \& Li Zhonghai. (2017). Research on the Impact of Institutional Investors on the Performance of Holding Companies-Based on the Perspective of Institutional Investors Self-protection. Journal of Management Science, 5. 82-101.

[7] Wang Xiaoyan \& Wen Dongzi. (2020). Institutional Investor Heterogeneity, Innovation Investment and Enterprise Performance - Empirical Data Based on GEM. Audit and Economic Research, 298-106.

[8] Li Yuedong, \& Yan Qing. (2017). Institutional Shareholding, Ultimate Property Rights and Internal Control Defects. Accounting Research, 5, 83-89.

[9] Niu Jianbo, Wu Chao \& Li Shengnan. (2013). Type of institutional investors, equity characteristics and voluntary information disclosure. Management Review, 348-59.

[10] Li Zhengguang, Zhao Xib, Cao Feng, \& Lu Xiaoxuan. (2014). Institutional Investor Heterogeneity and Corporate Performance - Empirical Evidence from Chinese Listed Companies. Audit and Economic Research, 29 (5), 77.

[11] Shavell, S. (1979). Risk sharing and incentives in the principal and agent relationship. The Bell Journal of Economics, 55-73.

[12] Smith, G., \& Swan, P. L. (2008). Will the Real Monitors Please Stand Up? Institutional Investors and CEO Compensation. Institutional Investors and CEO Compensation (February 21, 2008). Smith, M. P. (1996). Shareholder activism by institutional investors: Evidence from CalPERS. The journal of finance, 51 (1), 227-252.

[13] Li Chao, Cai Qingfeng, \& Chen Jiao. (2012). Can institutional investors improve the compensation incentive of executives in listed companies? Securities market guide, 1, 31-37. 
[14] Wu Xiancong. (2015). Did institutional investors influence executive compensation and its private earnings? Research on Institutional Investors Based on Different Characteristics. Foreign Economy and Management, 8, 13-29.

[15] Jensen, M. C., \& Murphy, K. J. (1990). Performance pay and top-management incentives. Journal of political economy, 98 (2), 225-264.

[16] Li Zhankui. (2017). Executive Incentive and Corporate Performance - Mediating Effect Based on R \& D Investment. Financial \& Accounting Newsletter, 35, 31-36.

[17] Wang Aiguo \& Xu Xiangzhen. (2015). Executive compensation, on-the-job consumption, compensation gap and enterprise performance - empirical data from Shanghai-Shenzhen listed central management enterprises in 2010-2012. Financial Research, 248-56.

[18] Fan Haifeng, \& Hu Yuming. (2012). Institutional investor ownership and corporate R \& D Expenditure: a theoretical and Empirical Study Based on Chinese securities market. Southern economics, 30 (9), 60-69.

[19] Jiang Yanhui, Tang Jia Cai,\& Yao Ka Hua. (2014). Institutional Investor Heterogeneity and R \& D Investment of Listed Companies: An Empirical Study from High-tech Enterprises in A-Share Market. Economic Journal, 4, 86-91.

[20] Aghion, P., Van Reenen, J., \& Zingales, L. (2013). Innovation and institutional ownership. American economic review, 103 (1), 277-304.

[21] Zhang Qiang, \& Wang Mingtao. (2019). Mechanism of institutional investor influence on enterprise innovation: empirical evidence from listed companies of small and medium-sized innovation boards. Scientific and technological progress and countermeasures, 13, 1-10.

[22] Vander Pal, G. (2015). Impact of R\&D expenses and corporate financial performance. VanderPal, GA (2015). Impact of R\&D expenses and corporate financial performance. Journal of Accounting and Finance, 15 (7), 135-149.

[23] Qiu Yunjie, \& Wei Wei. (2016). The impact of R \& D investment on Enterprise Performance: Based on the propensity score matching method. Contemporary finance, 3 (96), 106.

[24] Yin Meiquan, Sheng Lei, \& Li Wenbo. (2018). Executive Incentive, Innovation Input and Corporate Performance: An Empirical Study of Branch Business Based on Endogenous Perspective. Nankai Management Review, 1, 109-117.

[25] Qiu Xuelin,\& Liu Hao. (2019). Executive Performance Incentives, Managerial Competence and Corporate Performance. Financial and Accounting Newsletter, 830 (30), 25-33.

[26] Liu Wanli. (2020). Executive short-term compensation, risk taking and R \& D investment. China Soft Sciences, 7, 178-186.

[27] Yu Jing \& Cai Wen. (2021). An Empirical Analysis of the Impact of Executive Incentives on Enterprise Innovation: A Study of Intermediary Effects Based on Analyst Concern. Technology Economy, 1, 20-29.

[28] Wen Zhonglin, \& Ye Baojuan. (2014). Analysis of mediating effects: methods and model development. Advances in psychological science, 22 (5), 731-745.

[29] Liu Shishun,\& Ling Wenjian. (2009). Multimodal Model and Its Application. Psychological Science, 2, 433-435.

[30] Baron, R. M., \& Kenny, D. A. (1986). The moderator-mediator variable distinction in social psychological research: Conceptual, strategic, and statistical considerations. Journal of personality and social psychology, 51 (6), 1173.

[31] Dong Jiachang, Feng Tao \& Li Jialin. (2020). The impact of factor mismatch on the quality of economic development in China: An Empirical Test Based on the chain multiple mediating effect model. Finance and trade research, 5, 1-12. 